\title{
Environmental life cycle assessment for potable water production - a case study of seawater desalination and mine-water reclamation in South Africa
}

\author{
T Goga', E Friedrich"* and CA Buckley ${ }^{2}$ \\ 'Civil Engineering Programme, School of Engineering, University of KwaZulu-Natal, Durban, 4041, South Africa \\ 2Pollution Research Group, Chemical Engineering Programme, School of Engineering, University of KwaZulu-Natal, Durban, 4041, South Africa
}

\begin{abstract}
Water is becoming a scarce resource in many parts of South Africa and, therefore, numerous plans are being put in place to satisfy the increased urban demand for this resource. Two of the methods currently considered are desalination of seawater and reuse of mine-affected water based on the use of reverse osmosis (RO) membranes. Due to their high energy consumption and associated environmental impacts, these methods have been under scrutinity and, therefore, an LCA was undertaken for both methods. To allow comparison between the two, the functional unit of $1 \mathrm{~kL}$ of potable water was specified. Design data were collected for both the construction and operation phases of the plants while SimaPro was used as the LCA analysis software with the application of the ReCiPe Midpoint method. The results indicate that the operation phase carried a greater environmental burden than the materials required for the infrastructure. In particular, electricity production and consumption is responsible for the majority of environmental impacts that stem from the respective plants. The total energy consumption of the proposed desalination plant is $3.69 \mathrm{kWh} / \mathrm{kL}$ and $2.16 \mathrm{kWh} / \mathrm{kL}$ for the mine-water reclamation plant. This results in $4.17 \mathrm{~kg} \mathrm{CO} 2 \mathrm{eq} / \mathrm{kL}$ being emitted for the desalination plant and $2.44 \mathrm{~kg} \mathrm{CO}$ eq/ $\mathrm{kL}$ for the mine-affected plant. A further analysis indicated that replacing South African electricity with photovoltaic (solar) and wind power has the potential to bring significant environmental benefits. The integration of these renewable energy systems with desalination and membrane treatment of mine-affected water has been proven to reduce environmental burdens to levels associated with conventional water technologies powered by the current electricity mix.
\end{abstract}

Keywords: LCA, water treatment, mine water, desalination

\section{INTRODUCTION}

Water is regarded as one of the most precious and critical resources worldwide. In South Africa, the scarcity of water presents various challenges, mainly relating to efficient development, management and utilisation (Knüppe, 2011). To overcome these obstacles and ensure that South Africa has sufficient water supply, various water treatment techniques have been explored. As is the case with all industrial processes, there are substantial environmental impacts that occur from the construction of the infrastructure, through to commissioning, operation and decommissioning. In order to effectively evaluate the environmental burden of each water treatment system as well as its associated processes, a life cycle assessment (LCA) can be utilised. The use of such a sustainability tool provides a true reflection of the product's life cycle from 'cradle to grave' by systematically quantifying the amount of energy used, the consumption of raw materials, emissions to the atmosphere as well as the amount of waste generated (ISO, 2006).

The use of LCA as an assessment tool to gauge the environmental impacts of water technologies has been increasingly used since the late 1990s. Loubet et al. (2014) and Buckley et al. (2011) present a comprehensive review of the applications of environmental LCAs in the water industry both internationally and locally. Assessments have been successfully conducted locally for conventional technologies utilised in potable water and wastewater treatment plants (Friedrich et al., 2007); however, there are only two local studies researching

${ }^{\star}$ Corresponding author, email: Friedriche@ukzn.ac.za

Received 26 April 2018; accepted in revised form 25 September 2019 membrane processes. Internationally, such membrane processes have been the focus of many LCAs, with Meijers et al. (1998) starting this trend. Zhou et al. (2014) present an extensive review of the international studies employing LCAs for desalination and they include more than 30 individual research papers. Locally, there are only two such investigations (Friedrich, 2002; Ras and Von Blottnitz, 2012) that employ LCA for the use of membranes in the treatment of water. However, there are no such investigations for the local desalination of seawater or reclamation of mine-affected water. Therefore, this paper aims to satisfy this need by investigating the environmental burdens associated with membrane-based treatment processes.

This study compared two water treatment processes in South Africa to produce potable water. The first study is based on a proposed desalination plant that will be installed by Umgeni Water. During the feasibility study phase, it was determined that the plant should be located on the South Coast of KwaZulu-Natal and will be designed to produce a total of $150 \mathrm{ML} / \mathrm{d}$ of potable water (Umgeni Water, 2015a). The second study revolves around a water treatment process in Mpumalanga that treats mine-affected water to potable water standards. The plant is currently treating $15 \mathrm{ML} / \mathrm{d}$ of raw water via two processing trains (Golder Associates Africa, 2012). Both plants make use of membrane technologies to achieve the desired separation. Currently, these alternative sources of water and associated technologies are in rare use (DWA, 2013). However, considering the increasing demand for a limited resource, such operations will become more widespread. Thus, it is imperative to shape the design process for future projects from the outset, so as to reach the best outcome locally. The findings from this study will provide guidance regarding focus areas to guide this process. 
The LCA process consists of 4 phases, namely, goal and scope definition, inventory analysis, impact assessment and interpretation (ISO, 2006). The first stage set the aims of the study and provided an outline of the functional unit, assumptions made and data requirements. The next stage consisted of the gathering of data which was used as inputs into SimaPro which was the selected LCA software. A series of scores for the various environmental impacts were obtained which provided an indication of the environmental contribution of the process parameters. Recommendations based on these results were then proposed.

\section{CASE STUDIES}

The first case study centred around a proposed desalination plant in the Southern eThekwini area that makes use of RO technology. The second case study focused on a mine-water reclamation process in Mpumalanga that was designed using both UF and RO.

\section{Desalination plant in eThekwini Municipality}

To determine the feasibility of constructing a large-scale desalination plant, an investigation by Umgeni Water was initiated by undertaking a desalination pre-feasibility study. After much consultation, a revised strategy was adopted where the detailed feasibility study would consider the option of a $150 \mathrm{ML} / \mathrm{d}$ plant situated on both the North and South Coast (Meier, 2012). A diagram of the desalination process highlighting the key components is presented in Fig. 1. In general, the desalination plants at the selected locations would include the following key components (Umgeni Water, 2015a):

- Offshore open intake and discharge pipeline with diffusers

- Pipeline and structures conveying intake water to the desalination plant

- Pre-treatment facilities

- Reverse osmosis systems equipped with energy recovery devices

- Post-treatment systems for re-mineralization and disinfection

- Water storage tanks and pump stations

- Electrical substations connected to power grid
The desalination process centres around the RO system. It is recommended that the $\mathrm{RO}$ system consists of 16 seawater reverse osmosis (SWRO) trains with one high-pressure feed pump. This system must be designed to meet the specified product water quality and possess a certain degree of flexibility to accommodate potential increase in production or future changes in membrane technology (Umgeni Water, 2015a). Approximately $40-50 \%$ of the energy requirements for desalination are contained within the concentrate produced by the RO process. In order to optimise the energy consumption of the system, this energy can be recovered and reused by installing energy-recovery devices. It is noted in the Feasibility Report that the payback period of equipment costs for installation of these devices through energy savings is usually less than 5 years. Thus, the consulting engineers have suggested the addition of 16 pressure exchange recovery systems - one per SWRO train (Umgeni Water, 2015a).

\section{The mine-water reclamation plant in Mpumalanga}

Various coal mines in Gauteng and Mpumalanga have been in existence for a substantial period of time. In order to allow safe access to the coal reserves, water is pumped away from active areas and stored in previously mined underground cavities. The objective of the proposed Mine Water Reclamation Scheme (MWRS) was to abstract and treat the accumulated mine-water in order to increase the potable water supply and allow mining to occur within areas that were previously flooded (Golder Associates Africa, 2012).

It was proposed that the project will involve the construction and operation of the MWRS which would consist of mine-water abstraction points and delivery pipelines, a mine-water storage dam, a water treatment plant (WTP), sludge and brine ponds (for WTP waste), treated water supply pipelines and support infrastructure such as powerlines and access roads (Golder Associates Africa, 2012). The WTP would comprise of a raw water pond, pre-treatment and UF facilities as well as a two-stage $\mathrm{RO}$ system. It was envisaged that the project will be carried out in three phases with the aim of abstracting and treating a total of

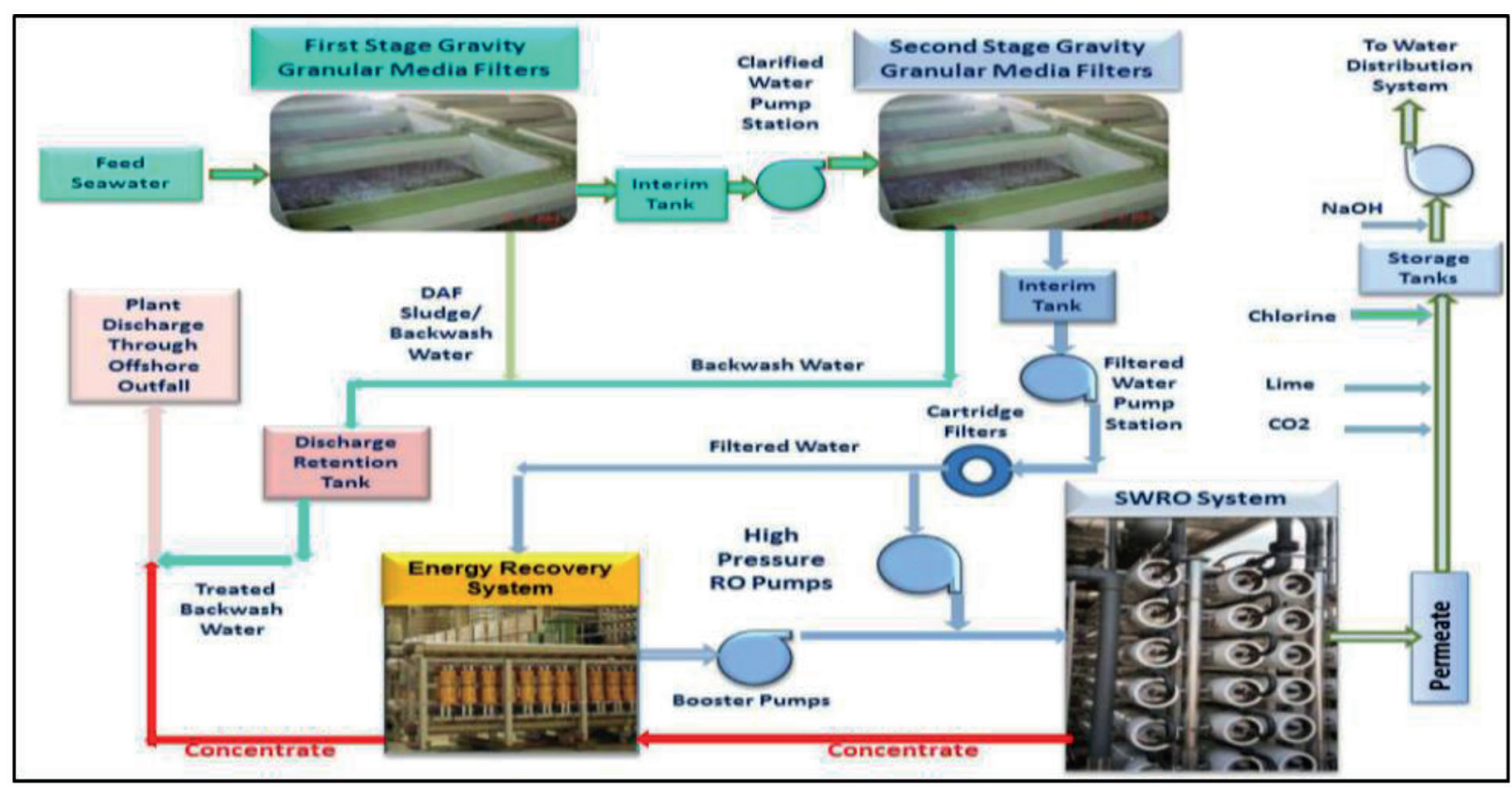

Figure 1. The proposed desalination process (Umgeni Water, 2015a) 
$45 \mathrm{ML} / \mathrm{d}$. At this stage, Phase 1 of the plant has been successfully completed which processes $15 \mathrm{ML} / \mathrm{d}$ of contaminated minewater (Golder Associates Africa, 2012).

The mine-water reclamation process commences with the pumping of the mine-affected water through deep bed up-flow (DUP) filters and treatment with the addition of several chemical compounds (Prentec, 2013). The water then flows through the first stage of UF and RO. The reject flow from this first stage then flows through a secondary treatment phase. At present, the product water from both stages is collected and then discharged into a river. All process units are housed in customised modules and integrated with process, mechanical, electrical and control components for full functionality and ease of design (Prentec, 2013). It is envisaged that future uses of this treated water would include the mine's internal use (4 ML/d), the proposed power plant (1.2-1.7 ML/d) and possible potable water supply to the surrounding communities (Golder Associates Africa, 2012).

The design for the mine-water reuse plant makes extensive use of membranes with two stages of UF and RO. The primary UF module consists of polyvinylidene fluoride (PVDF) membranes with $0.08 \mu \mathrm{m}$ pore size (Hydranautics, 2016). Stage 1 of RO is configured into two banks of spiral-wound elements with polyamide thin-film composite membranes with a $75-80 \%$ recovery (Dow Filmtec, 2015). The secondary treatment stage is designed to effectively recover water from a saline solution. Stage 2 of UF utilises $1.5 \mathrm{~mm}$ membranes with an inside-out configuration to reduce the potential for scaling (Prentec, 2013). The modified polyethersulphone (PES) membrane material is resistant to fouling while the large $1.5 \mathrm{~mm}$ size allows for a more effective cleaning process (Prentec, 2013). The second stage of RO comprises of three banks of membrane elements with a higher feed pressure than the first stage (Prentec, 2013).

\section{METHODOLOGY}

For this investigation an LCA methodological approach as defined by ISO 14040 (2006) was undertaken and the four major steps (goal and scope definition, inventory analysis, impact assessment and interpretation) were followed.

\section{Goal and scope definition}

The main goal of this study was to quantify the overall environmental impact of each of the selected cases of membrane water treatment processes with the generation of local LCA data. The intended audience for this study is broad and includes environmental and operational managers in the water sector. It is envisaged that government authorities who are responsible for investigating environmental processes could also gain insight from the findings of such a research project.

The purpose of defining the scope is to provide sufficient detail regarding the object of the LCA study. This should be completed in conjunction with the goal definition (European Commission, 2010). The items that need to be considered include the product system demarcated by the system boundaries, the selected function and functional unit, data requirements and assumptions and limitations made during the course of the study.

The systems under consideration are the two processes for the production of potable water. The first process under review was the desalination of seawater while the second process focuses on the reclamation of mine-affected water. For

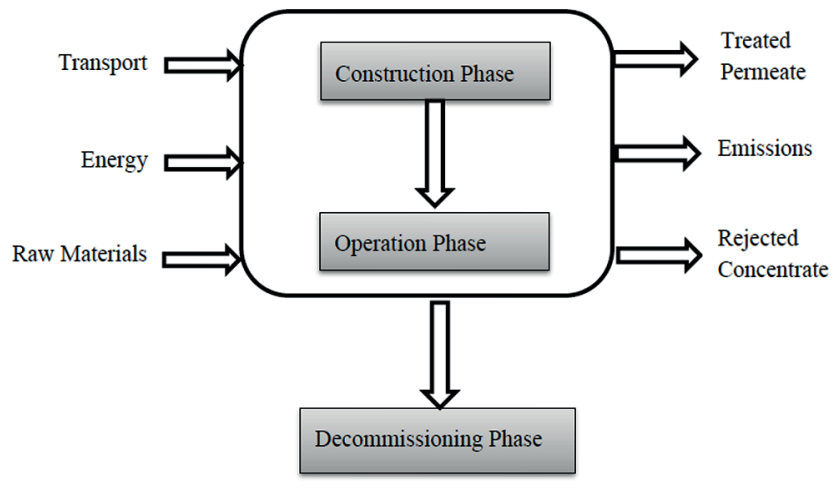

Figure 2. LCA stages included for the desalination and treatment of mine-affected water processes investigated

both processes, the construction and operation phase were considered as the decommissioning phase was considered negligible based on the findings of Friedrich (2001) and Raluy et al. (2005). Figure 2 depicts the stages in the LCA with the black box depicting the system boundary.

The function for both systems is identical, i.e., to produce potable water of a certain quality. The functional unit for this study was $1 \mathrm{~kL}$ of water at the specified standard for potable water produced over the lifespan of each process unit. The selection of this particular functional unit enabled a reference to which all inputs and outputs are related. It should be noted that this functional unit was chosen due to the demand for potable water. The mine-affected water would have had to be treated as per current South African guidelines before being released into the environment. However, the quality would have been required to meet a much lower standard as compared to that of potable water. For seawater there is no need for treatment in the absence of the potable water demand. For the purpose of this study the potential treatment of mine-affected water in the absence of potable water demand was neglected, as in reality the membrane processes would not have been employed if not for the need for potable water quality.

Data quality requirements are a general indication of the characteristics of the data for the study. For both case studies, data that were directly obtained from the feasibility and design reports were preferable. Such data included the consumption of electricity and chemicals. For process flows within the system that were not available, mass balances were employed. When direct data was unavailable, as was the case for the construction of civil engineering structures, calculations based on technical literature were utilised. Several calculations were often undertaken and the highest values, representing a worstcase scenario, were used for purposes of the study. Decisions regarding materials of construction as well as equipment types were based on case studies of similar water treatment processes. The geographical area for data gathering was South Africa. Within the SimaPro databases, South African data were only available for national electricity and mined coal that was used as filter media. For the remainder of the inputs, European or global figures were utilised.

Limitations to a certain extent were to be expected, considering the task of accounting for all inputs and outputs of the system. In general, data were found to be sparse and lacking which is often the case for LCAs, but even more so for industries based in South Africa. One problem that was encountered was that data were considered to be confidential and thus were not easily accessible. This was the case for both 
case studies and lengthy negotiations had to occur before any exchange of information happened. Agreements between Umgeni Water, Prentec and the consulting engineers had to be made in order to obtain certain process details. Another reason for the lack of data can be attributed in part to the fact that the desalination plant was still in the early design phases. Thus, some information, such as the weights of certain pumps, was unavailable. As a result, information from design specification sheets for similar pumps had to be used as inputs for the calculations. For the mine-water reclamation plant, design data rather than operational data had to be utilised. This was due to changes in the feed quality of the source water which affected the operation of the plant.

A set of assumptions had to be made in order to bridge data gaps. For certain inputs that were based on international data, it was assumed that the technology and equipment utilised will perform in a similar manner to what is used in South Africa. Where the material of construction was unspecified for components such as the filter cells, various literature sources were perused and the most common materials were selected for the purpose of calculation. In other instances, super duplex stainless steel was chosen as the construction material of choice for any equipment that is in contact with the ocean water. It was also assumed that both plants will be operational for the entire year, i.e. 365 days with no allowance for shutdown periods. This was to account for the worst-case scenario.

\section{Inventory analysis}

As the second stage of the LCA process, the inventory analysis consisted of collecting environmentally relevant data as well as formulating equations in order to quantify the flows into and out of the system. For this particular study, the process of data collection and compilation was the most work-intensive and time-consuming activity.

\section{Data collection for the desalination plant}

The procedure for data collection started off with a compilation of a process flow diagram (PFD) which highlighted the significant flows and operations within the system. From this point, a spreadsheet was drawn up which included material and energy inputs and outputs for each unit operation. For the construction phase, four major components were analysed: civil engineering structures, pipes, pumps, filters and membranes. Civil engineering structures consisted of fixtures such as tanks, pillars and filter cells. The weights of these constituents were generally not stated and had to be calculated based on available dimensions provided in the feasibility reports. In the event that the material of construction was not specified, technical literature was used to select the most appropriate building material.

In the case of pipes, all pipes were specified to be constructed of high density polyethylene (HDPE) due to its higher durability, non-corrosive nature and lower construction and maintenance costs compared to other materials. The mass of these pipes was calculated by firstly calculating volume of a hollow cylinder (which represents a pipe) using the inside and outside diameters, subtracting the volume of the inner from the outer and using the density to obtain the mass. The second method used a HDPE pipe brochure to obtain the mass of the pipe based on the outer diameter and standard dimension ratio (SDR) class which were stated in the Pipelines and Pump Stations Report (Umgeni Water, 2015b). The higher figure was then utilised in subsequent calculations.

Pumps are a fundamental part of the infrastructure of any plant and the design for the proposed desalination plant was no different. For the intake pumps, options were provided for various pump models in the above-mentioned report that detailed pipe specifications (Umgeni Water, 2015b). The mass was then obtained from locating the pump specification sheets for the selected model. For other pumps where model numbers were unavailable, the installed motor size and pumping capacity which was provided in the Desalination Options and Feasibility Report (Umgeni Water, 2015a) were used as guidelines to select an appropriate pump. The masses of the respective pumps were taken as a single entity inclusive of parts such as motors, gears, bearings, casings, etc. This was due to difficulty experienced in obtaining these figures. The Feasibility Report also detailed that the pumps be constructed of super duplex stainless steel. As such a material was not available on the SimaPro database, steel which had a high chromite content $( \pm 25 \%)$ was selected.

For the production of potable water, the main operational inputs into the system were the energy consumed, the chemicals utilised and the filter media, as displayed in Table 1. There were a range of chemicals used in the production process with the majority being used in the pre-treatment and post-treatment phase. Chemicals were used for various purposes: disinfection, $\mathrm{RO}$ membrane cleaning, chlorination and re-mineralisation. The utilisation of chemicals was stated in terms of milligrams per litre of water $(\mathrm{mg} / \mathrm{L})$ with the majority of the chemicals specified. For the chemicals that were not categorically stated, such as the coagulant and antiscalant, research was undertaken to determine the most suitable chemical for the application. Table 1

Table 1. Summary of chemicals used for the desalination process

\begin{tabular}{lll}
\hline $\begin{array}{l}\text { Chemical } \\
\text { (Umgeni Water, 2015a) }\end{array}$ & $\begin{array}{l}\text { Unit } \\
\text { operation }\end{array}$ & $\begin{array}{l}\text { Chemical } \\
\text { (SimaPro) }\end{array}$ \\
\hline $\begin{array}{l}\text { Sodium hyphochlorite } \\
\text { Coagulant, flocculant }\end{array}$ & $\begin{array}{l}\text { Screening of water } \\
\text { Sulphuric acid }\end{array}$ & $\begin{array}{l}\text { Sodium hyphochlorite } \\
\text { Iron (III) chloride (40\% solution) }\end{array}$ \\
Sodium hydroxide & Pre-treatment - both stages & Sulphuric qcid \\
Sodium bisulfite & Pre-treatment - second stage & Sodium hydroxide (50\% solution) \\
Antiscalant & Pre-treatment - second stage & Sodium sulfite \\
Membrane cleaning & Pre-treatment - second stage & Phosphoric acid \\
Lime & Reverse osmosis & Hydrochloric acid (30\% solution) \\
Carbon dioxide & Post-treatment & Lime (hydrated) \\
Chlorine & Post-treatment & Carbon dioxide (liquid) \\
Sodium hydroxide & Post-treatment & Chlorine (gaseous, membrane cell) \\
\hline
\end{tabular}


provides a summary of the chemical usage for the desalination process. The first and second column lists the chemicals mentioned in the Umgeni Water report as well as the unit operation. The last column states the chemical that was utilised in SimaPro based on technical literature.

From the literature review, it is evident that the electricity requirement has always been one of the determining factors regarding life cycle assessment results. For the purposes of this study, this information was available in the Feasibility Report and was expressed in terms of $\mathrm{kWh} / \mathrm{m}^{3}$ (Umgeni Water, 2015a). As electricity is such a fundamental element, it was imperative that a consistent and representative life cycle inventory (LCI) of electricity supply was utilised. The latest version of ecoinvent (version 3) offers new LCI data of power supply in 71 geographical locations which includes South Africa (Paul Scherrer Institute, 2012). Thus, this inventory set was utilised for this study to account for the South African energy mix.

The filtration step forms part of the pre-treatment phase to protect the $\mathrm{RO}$ membranes further on in the process. As mentioned in the previous sub-section, dual media filters were specified in both stages of pre-treatment containing silica sand, anthracite and garnet. SimaPro contains data for coal from extraction to point of sale in South Africa. This local dataset was utilised to represent the media layers for the filters.

\section{Data collection for the mine-water reclamation plant}

This procedure commenced with an initial meeting with the senior process engineer from Prentec. An overview of the treatment process was provided together with several process and instrumentation diagrams (PIDs) as well as schedules for power use. This was followed by the compilation of the spreadsheet that segregated the design data per unit operation and then further into the construction and operation phases. Average design feed flows into each sub-operation were stated in the design reports.

The major constituents of the construction phase for this case study comprised of components such as civil engineering structures, frames of the modules, grating, pipes, pumps, filters and membranes. The civil engineering structures for this case study consisted of tanks and filter cells. Design sheets for the various tanks provided dimensions of the tanks such as the diameters and heights. This was utilised to calculate the circumference and thereafter the number of panels that make up the wall of the tank. Together with the dimensions of the panel, the weight of the walls and base of the tank can be calculated. From the design sheets, the material of construction for the base and walls was reinforced concrete to withstand pressures of 25 and $30 \mathrm{MPa}$, respectively. With respect to working life, the senior process engineer was consulted and agreed that a reasonable working life for tanks would be 50 years.

For this case study, the mass of components, such as the frames of the skid, grating and pipes, were obtained courtesy of the personnel from the company involved. A 3D model of the plant, which collates the total mass of each skid, was utilised, from which masses of the individual items were extracted. These data are extremely accurate as pipe mass would include the mass of all lengths of pipe including all bends and tees. The frames and grating that form part of the skid are constructed of carbon steel and galvanised steel, respectively, while the pipes are either assembled from PVC or stainless steel. As advised by the design engineer, the working life of the frames, grating and stainless steel pipes was taken as 25 years while the PVC pipes were assumed to last 20 years.
With respect to the pumps, product names were provided in the design proposal report. As the majority of the pumps were manufactured by Grundfos, the product centre on the Grundfos website was perused. As all the pumps were classified as 'end suction close coupled' (NB range), the pump catalogue was browsed by pump design to locate the masses of the specific pumps. As in the initial case study, the masses of the respective pumps were taken as a single entity inclusive of all internal mechanical parts. The working life of all pumps was stated as 7 years.

The water treatment process for mine-affected water consists of two stages of treatment. Thus, there were two stages of reverse osmosis and two stages of ultrafiltration (UF). For the RO membranes, the masses of 8 " spiral wound membranes were obtained from the Dow website while the design sheets for the glass-reinforced plastic vessels were provided. According to the engineer as well as figures from technical literature, the membranes which are constructed of polysulphone would last an average of 5 years while the working life of the outer shells was noted as 20 years. With respect to the UF membranes, product data sheets for the weight of membranes were located on the supplier's website. These were constructed of polyvinyl chloride (PVC) with the same working life as the RO membranes.

The three components in the operation phase include the chemical use within the process and the energy consumption as well as the filter media used. There were numerous chemicals used in the treatment process to satisfy various objectives. Amongst them were coagulants, biocides, antiscalants, chemically enhanced backwash (CEB) and clean-inplace (CIP) chemicals. The major chemical constituents used were phosphoric acid as an antiscalant, ferric chloride as a coagulant and secondary antiscalant, sodium hydroxide, sodium hypochlorite and hydrochloric acid as CEB and CIP chemicals. The average concentrations in terms of ppm for each chemical were provided.

From the literature, it was evident that energy was of utmost importance. Thus, a concerted effort was made to obtain an accurate portrayal of the electricity consumption within the process. The power used by each unit operation expressed as kilowatts was obtained from a design schedule. Together with the design feed rate into each area, the electricity requirement in terms of $\mathrm{kWh} / \mathrm{m}^{3}$ was calculated. As with the first case study, the South African electricity (medium voltage) dataset in SimaPro was utilised.

To fulfil the purpose of pre-treatment, DUP filters were employed prior to the membrane treatment stages. The filter media consisted of two layers: silica sand and magnetite. As in the case of the desalination process, the local data available in SimaPro were utilised to represent both media layers for the filtration process.

\section{Input into SimaPro}

For an effective assessment, all data had to be scaled down in accordance with the functional unit. Thus, all material data were expressed in terms of $\mathrm{kg} / \mathrm{kL}$ potable water, energy inputs as $\mathrm{kWh} / \mathrm{kL}$ potable water and chemicals used as $\mathrm{mg} / \mathrm{kL}$ potable water. Once this information was in the relevant format, it could be used as inputs into the SimaPro LCA Software. Within the SimaPro programme, new projects depicting both processes were created. In addition, each unit operation was developed as an individual process together with the appropriate inputs and outputs.

The result of the inventory analysis was the generation of an inventory table. This is as a result of the 'analyse' function 
used in SimaPro which, through a reduced matrix, calculates the system inventory by constructing the process network and tracing the movement of materials from one stage to another. The software presents the table as a single list that is itemised alphabetically. This list is used as an input into the following phase, the impact assessment phase, which seeks to understand the contribution of the various processes to the overall environmental burden.

\section{Impact assessment}

The impact assessment phase aims to establish a link between the product system and potential environmental impacts. To achieve this objective, inventory information is related to relevant impact categories and indicators. Furthermore, this phase provides a basis for the next stage, i.e., life cycle interpretation.

The ISO 14042 (2000) document stated that there are three compulsory steps that need to be completed: selection and definition of impact categories, classification and characterisation. In addition, there are several optional elements that can be used, dependent on the goal and scope of the study: normalisation, grouping, weighting and data quality analysis. For the purposes of this study, the three mandatory elements were deemed sufficient and were thus performed for the system. The optional steps were excluded to avoid introducing a degree of subjectivity to the study.

The SimaPro 8.1.1.16 Software contains various impact assessment methods. For the study, the ReCiPe Midpoint Method was used. At this level, 18 impact categories are defined: climate change, human toxicity, ionising radiation, photochemical oxidant formation, particulate matter formation, terrestrial acidification, ozone depletion, terrestrial ecotoxicity, agricultural land occupation, urban land occupation, natural land transformation, marine ecotoxicity, marine eutrophication, fresh water eutrophication, fresh water ecotoxicity, fossil fuel depletion, minerals depletion and fresh water depletion. The full set of 18 impact categories has been used due to availability and completeness.

\section{Interpretation}

As the final stage in the LCA study, the interpretation phase aims to analyse the results from the previous phase and draw

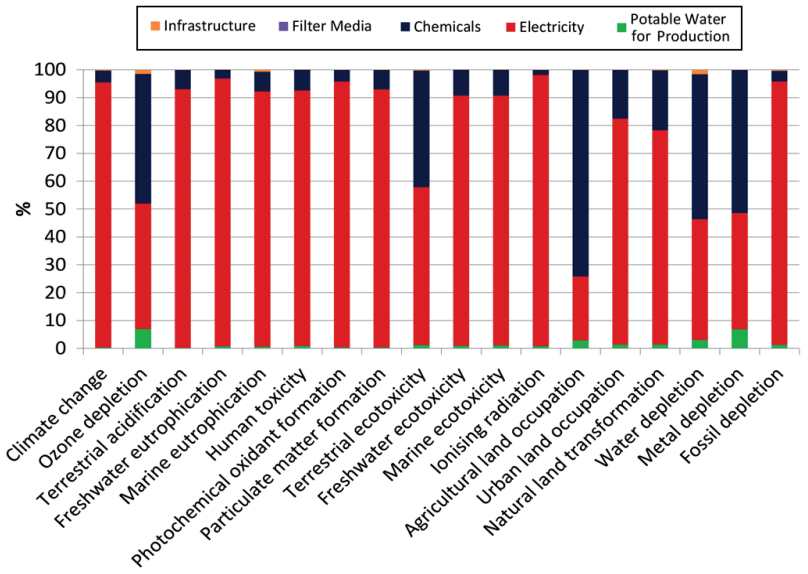

Figure 3. Impact assessment results (ReCiPe Midpoint V1.12 / World Recipe $\mathrm{H}$ / Characterisation Method) for the desalination process for $1 \mathrm{~m}^{3}$ potable water appropriate conclusions and recommendations.

For the interpretation phase, one $\mathrm{kL}\left(\mathrm{m}^{3}\right)$ of potable water for distribution was analysed by the ReCiPe method. As data were collected pertaining to the construction and operation phases, it was decided to firstly segregate the environmental impacts in terms of these two phases. This was possible through the 'analyse groups' function in SimaPro which provides the user with an opportunity to select and compare the impact of various operations or inputs in terms of the available categories. The results were presented in a tabular format which provided an overview of the contributions of the individual subprocesses. In addition, each impact category was also examined in greater detail with the results depicted in a network diagram which produces a visual representation of each input's contribution to the overall impact of the process.

\section{RESULTS}

The analysis of the results obtained from the study form part of the final phase of the LCA methodology which is Life Cycle Interpretation. The resulting evaluation would be utilized to reach suitable conclusions and provide relevant recommendations.

\section{Results for the desalination process}

Figure 3 illustrates the contribution of the various inputs to the relevant impact categories that are pre-defined in the software package as part of the ReCiPe impact assessment method. From the diagram, it is evident that electricity has an overwhelming burden contribution in 11 of 18 of the categories, such as climate change and terrestrial acidification. However, in other categories such as water, ozone and minerals depletion, the contribution of electricity is much lower (approximately 40 to $50 \%$ ) and as low as $25 \%$ for agricultural land occupation, with the chemical usage becoming more prominent. It is also interesting to note that the infrastructure carries a relatively insignificant burden compared to the other two inputs.

For the mine-water reclamation process (Fig. 4), electricity consumption has the greatest contribution to the bulk of the impacts. In the case of impact categories such as climate change and terrestrial acidification, the energy usage is

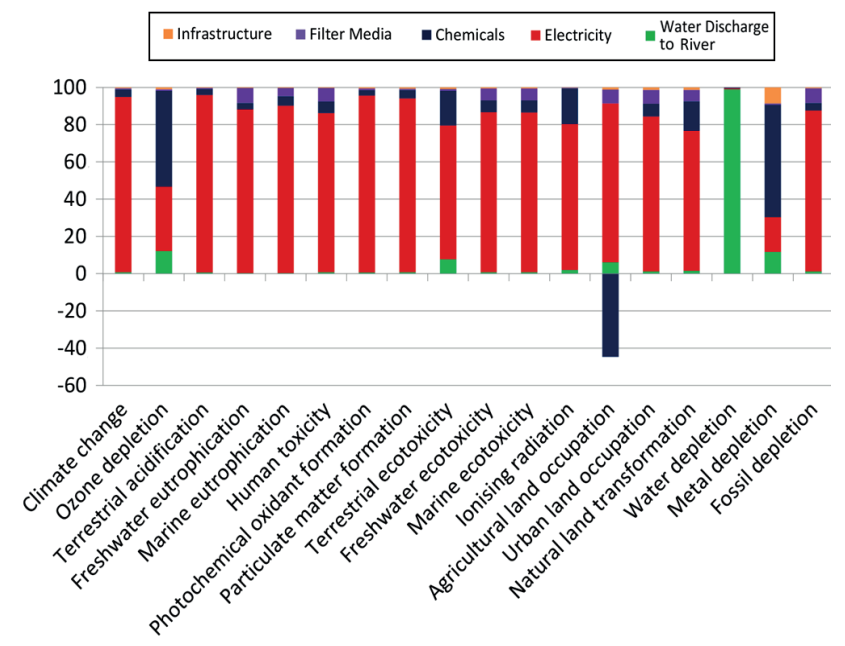

Figure 4. Impact assessment results for the mine-water reclamation process for $1 \mathrm{~m}^{3}$ treated water at a quality suitable for river discharge 
responsible for greater than $95 \%$ of the overall impact. In the case of other impacts, e.g., ozone and metal depletion, chemical consumption within the water treatment process carries a much more significant environmental burden as it accounts for approximately half of the total impact. The results also indicate that chemical usage had a positive environmental impact on agricultural land occupation. This is due to the use of two chemicals, ferric chloride and hydrochloric acid, attributed to the manufacture of chlorine and associated use of wood chips. Unlike the operation phase, the environmental impact of the infrastructure phase, which encompasses materials used in the construction of the plant, is relatively less significant.

\section{Desalination and mine-water reclamation environmental scores}

Once the results for the individual categories for each case study had been analysed, a comparison between the two water treatment processes was made. Table 2 provides a summary of the total environmental impacts. The figures highlight the fact that the desalination process carries a much higher overall burden compared to the mine-water reclamation

Table 2. Scores for the impact assessment results for desalination and mine-water reclamation (per $\mathrm{m}^{3}$ potable water produced)

\begin{tabular}{llcc}
\hline Impact category & Unit & Desalination & $\begin{array}{c}\text { Mine-water } \\
\text { reclamation }\end{array}$ \\
\hline Climate change & $\mathrm{kg} \mathrm{CO}$ eq & 4.40 & 2.60 \\
Ozone depletion & $\mathrm{kg} \mathrm{CFC}-11$ eq & $7.92 \times 10^{-8}$ & $6.05 \times 10^{-8}$ \\
Terrestrial acidification & $\mathrm{kg} \mathrm{SO}_{2}$ eq & $4.17 \times 10^{-2}$ & $2.37 \times 10^{-2}$ \\
Freshwater eutrophication & $\mathrm{kg} \mathrm{Peq}$ & $3.00 \times 10^{-3}$ & $1.92 \times 10^{-3}$ \\
Marine eutrophication & $\mathrm{kg} \mathrm{N} \mathrm{eq}$ & $1.42 \times 10^{-3}$ & $8.45 \times 10^{-4}$ \\
Human toxicity & $\mathrm{kg} \mathrm{1,4-DB} \mathrm{eq}$ & 2.05 & 1.29 \\
Photochemical oxidant formation & $\mathrm{kg} \mathrm{NMVOC}$ & $2.07 \times 10^{-2}$ & $1.21 \times 10^{-2}$ \\
Particulate matter formation & $\mathrm{kg} \mathrm{PM10} \mathrm{eq}$ & $1.08 \times 10^{-2}$ & $6.29 \times 10^{-3}$ \\
Terrestrial ecotoxicity & $\mathrm{kg} \mathrm{1,4-DB} \mathrm{eq}$ & $1.00 \times 10^{-4}$ & $4.61 \times 10^{-5}$ \\
Freshwater ecotoxicity & $\mathrm{kg} 1,4-\mathrm{DB}$ eq & $6.07 \times 10^{-2}$ & $3.70 \times 10^{-2}$ \\
Marine ecotoxicity & $\mathrm{kg} \mathrm{1,4-DB} \mathrm{eq}$ & $5.75 \times 10^{-2}$ & $3.51 \times 10^{-2}$ \\
lonising radiation & $\mathrm{kBq} \mathrm{U235} \mathrm{eq}$ & $2.33 \times 10^{-1}$ & $1.69 \times 10^{-1}$ \\
Agricultural land occupation & $\mathrm{m}^{2} \mathrm{a}$ & $2.91 \times 10^{-1}$ & $2.53 \times 10^{-2}$ \\
Urban land occupation & $\mathrm{m}^{2} \mathrm{a}$ & $2.03 \times 10^{-2}$ & $1.15 \times 10^{-2}$ \\
Natural land transformation & $\mathrm{m}^{2}$ & $1.27 \times 10^{-4}$ & $7.63 \times 10^{-5}$ \\
Water depletion & $\mathrm{m}^{3}$ & $1.93 \times 10^{-2}$ & 1.02 \\
Metal depletion & $\mathrm{kg} \mathrm{Fe} \mathrm{eq}$ & $1.05 \times 10^{-1}$ & $1.38 \times 10^{-1}$ \\
Fossil depletion & $\mathrm{kg} \mathrm{oil} \mathrm{eq}$ & 1.09 & $6.97 \times 10^{-1}$ \\
\hline
\end{tabular}

process. For the bulk of the categories such as climate change and terrestrial acidification, desalination displays scores that are approximately double the impact associated with minewater reclamation. There are two categories where mine-water reclamation performs worse than desalination: water and metal depletion. This can be attributed to the process of extracting the groundwater from abandoned mines, thereby adversely affecting the water and metal content in the surrounding environment. Furthermore, the significant depletion of water for the mine-water reclamation process is mainly due to the source water. In the case of desalination, the impact assessment method utilized does not consider water depletion of seawater. Hence, the figure for overall water depletion for desalination is significantly lower then that for mine-water reclamation. These assumptions mirror the water situation in the country - the scarcity of fresh water in general, and the abundance of seawater for costal cities in South Africa.

Although a comparison between the water treatment processes can be made, there are associated challenges and difficulties as the operations differ in many respects. Table 3 highlights a few of the significant differences between the two processes. The ISO 14040 (2006) document states that the results of various LCA studies can only be directly compared if the assumptions and context of each study are the same.

Both the water treatment processes discussed in the study are secondary processes which are necessary to implement due to the scarcity of water. In addition, there are also practical considerations that need to be taken into account prior to the design of these plants. Due to its feed source, the desalination plant has to be constructed in coastal areas with close proximity to seawater. As the mine reclamation plant will have to treat accumulated water from previously mined areas, the plant will reside close to the mines. The feed water quality for mine-water reclamation is also a significant factor due to variances in source water. This occurs as a result of different minerals being mined as well as the age of the mine. The quality of the mine-water to be treated is the main factor why the results for the current mine-water cannot be generalised to other mine-affected waters from other locations and/or mines.

\section{Energy requirements and the potential for improvement}

Energy consumption is an important cost and environmental factor for all water treatment processes, and especially for desalination. Therefore, benchmarking energy consumption is of value. In South Africa, it has been proposed that electricity consumption be used as a crude environmental indicator

Table 3. Summary of the differences between the desalination and mine-water reclamation processes

\begin{tabular}{lll}
\hline Aspect & Desalination & Mine-water reclamation \\
\hline Stages of treatment & Single stage & Two stage \\
\hline Feed water salinity & Feed water salinity: & Feed water salinity (Stage 1) \\
& $38000 \mathrm{mg} / \mathrm{L} \mathrm{TDS}$ & $3800 \mathrm{mg} / \mathrm{L}$ TDS \\
& & Feed water salinity (Stage 2) \\
& & $12000-17000 \mathrm{mg} / \mathrm{L}$ TDS \\
\hline Water treatment & $40-45 \%$ & $95-98 \%$ \\
recovery & & \\
\hline Infrastructure & Larger proportion of concrete construction & Larger proportion of steel construction \\
\hline Post-treatment & Water stabilised before discharge into potable & Water non-stabilised before discharge into river \\
\hline Reject stream & water supply network & Brine to be treated further - not included in case study \\
& Brine is discharged to sea (55-60 \% of feed) & (2-5\% of feed) \\
\hline
\end{tabular}


for the performance of urban water systems (Friedrich et al., 2009). In terms of energy requirements, seawater membrane desalination with energy recovery devices generally consumes about $3.5-4.5 \mathrm{kWh} / \mathrm{m}^{3}$ of electricity according to Vince et al. (2008) and between 4 to $6 \mathrm{kWh} / \mathrm{m}^{3}$ according to Abdelkareem et al. (2017). The desalination of brackish water needs about 1.5 to $2.5 \mathrm{kWh} / \mathrm{m}^{3}$ (Abdelkareem et al., 2017). The local desalination process investigated in this study should need a total of $3.69 \mathrm{kWh} / \mathrm{m}^{3}$ which is within the above-mentioned ranges. Furthermore, it is lower than the stated electricity consumption of the three operational desalination plants in South Africa: the Sedgefield Plant $\left(3.97 \mathrm{kWh} / \mathrm{m}^{3}\right)$, the Albany Coast Plant $\left(4.52 \mathrm{kWh} / \mathrm{m}^{3}\right)$ and the Mossel Bay Plant $\left(4.39 \mathrm{kWh} / \mathrm{m}^{3}\right)$ (Turner et al., 2015). However, this figure has to be validated and monitored once the desalination plant will become operational.

A further assessment regarding energy consumption was undertaken comparing the environmental impacts of alternative water treatment plants to a conventional water treatment plant in South Africa. At the outset, it must be acknowledged that the energy requirement for desalination and mine-water reclamation is much greater than other water treatment technologies. When considering the conventional treatment of raw wastewater in the local context, the Wiggins Waterworks had the highest electricity consumption per kilolitre of water produced at $0.10 \mathrm{kWh} / \mathrm{m}^{3}$ which represents the worst-case scenario for the eThekwini Municipality (Friedrich et al., 2009). The total energy consumption of the proposed desalination plant is $3.69 \mathrm{kWh} / \mathrm{m}^{3}$ and $2.16 \mathrm{kWh} / \mathrm{m}^{3}$ for the mine-water reclamation plant. Taking the above two figures for energy usage and associating them with characterisation factors for climate change due to the use of renewable energy sources (sun and wind) yields the results in Table 4 . In addition, the South African 2030 electricity mix as described in the Integrated Resource Plan - Scenario IRP 1 (DoE) 2018) was modelled to represent a realistic situation for the future energy requirement of both water treatment plants. This scenario assumes that by 2030 the South African electricity mix will be from coal (64\%), wind (13\%), solar energy (8\%), nuclear energy (4\%), hydro energy (3\%), gas (1\%) and others (5\%). It is the most conservative scenario presented in the planned integrated resource plan for South Africa (DoE, 2018). Although less than $1 \%$ of the RO desalination plants worldwide are currently powered by renewable sources, their use is predicted to increase in the future (Abdelkareem et al., 2017).
The figures in Table 4 demonstrate that desalination using wind and solar power has the potential to produce GHG emissions in the range of $0.07-0.28 \mathrm{~kg} \mathrm{CO}_{2} \mathrm{eq} / \mathrm{kL}$ potable water. The release of GHG emissions for the mine-water reclamation plant will be even lower with emissions between 0.04 and $0.16 \mathrm{~kg} \mathrm{CO}, \mathrm{eq} / \mathrm{kL}$ potable water. These figures are comparable to the emissions of $0.08-0.11 \mathrm{~kg} \mathrm{CO}, \mathrm{eq} / \mathrm{kL}$ water, which would be released from the conventional water treatment processes employed at Durban Heights and Wiggins Waterworks. These are the two most important Umgeni Water potable water plants in the eThekwini Municipality (core city Durban).

The figures in Table 4 for renewable energy sources represent an ideal best-case scenario which in reality cannot be achieved by membrane plants of the sizes of those investigated in this study. Large RO plants usualy need storage and backup and, therefore, practically cannot rely $100 \%$ on renewable energy. However, in the literature a series of authors (Biswas et al., 2009; Stokes et al., 2009 and Shahabi et al., 2014) have used $100 \%$ wind energy and $100 \%$ solar energy for similar studies involving $\mathrm{RO}$ in order to gauge a best-case scenario. From an implementation and practical point of view, Chew and $\mathrm{Ng}$ (2019) also used $100 \%$ solar power in this manner for a small pilot plant for ultra-filtration membranes to be used for rural (off-grid) water supply in Malaysia. In the South African context this is an unrealistic best-case scenario which can only be theoretically considered for plants of the size of those investigated in this study.

The South African 2030 electricity mix (64\% coal, wind $13 \%$, solar $8 \%$, nuclear $4 \%$, hydro $3 \%$, gas $1 \%$ and other $5 \%$ ) was modelled to represent a realistic situation for the future energy requirement of membrane-based plants in South Africa. Results indicate that that desalination using the predicted 2030 energy mix has the potential to produce $1.16 \mathrm{~kg} \mathrm{CO}_{2} \mathrm{eq} / \mathrm{kL}$ potable water. The release of GHG emissions for the mine-water reclamation plant will be even lower at $0.678 \mathrm{~kg} \mathrm{CO}_{2} \mathrm{eq} / \mathrm{kL}$ potable water. This shows that a reduction in coal-fired energy coupled with an increase in the use of renewable energy sources has the potential to decrease the carbon footprint of water treatment plants that use alternative feed sources. These are more realistic calculations for the local context.

The results presented in Table 4 are in line with similar results from other studies. For example, Raluy et al. (2004) reported that a reduction of greater than $35 \%$ is expected, dependent on the origin of the energy, i.e., cogeneration, internal combustion engine or a combined cycle (Raluy et al.,

Table 4. Comparison between greenhouse gas emissions for water treatment processes employing various energy sources

\begin{tabular}{|c|c|c|c|}
\hline Plant & Energy source & $\begin{array}{l}\text { Characterisation factors } \\
\left(\mathrm{kg} \mathrm{CO} \mathrm{O}_{2} \text { eq }\right)\end{array}$ & $\begin{array}{c}\text { Climate change } \\
\text { (kg CO}{ }_{2} \text { eq/kL water) }\end{array}$ \\
\hline \multirow[t]{4}{*}{ Desalination plant } & Conventional electricity & 1.13 & 4.17 \\
\hline & Photovoltaic (Sun) & $7.52 \times 10^{-2}$ & 0.28 \\
\hline & Wind & $1.85 \times 10^{-2}$ & 0.07 \\
\hline & $\begin{array}{l}\text { South African energy mix } 2030 \text { - IRP } 1 \\
\text { Scenario (DoE, 2018) }\end{array}$ & 0.314 & 1.16 \\
\hline \multirow{4}{*}{$\begin{array}{l}\text { Mine-water reclamation } \\
\text { plant }\end{array}$} & Conventional electricity & 1.13 & 2.44 \\
\hline & Photovoltaic (sun) & $7.52 \times 10^{-2}$ & 0.16 \\
\hline & Wind & $1.85 \times 10^{-2}$ & 0.04 \\
\hline & $\begin{array}{l}\text { South African energy mix } 2030 \text { - IRP } 1 \\
\text { Scenario (DoE, 2018) }\end{array}$ & 0.314 & 0.68 \\
\hline Wiggins Waterworks & Conventional electricity & 1.13 & 0.11 \\
\hline Durban Heights & Conventional electricity & 1.13 & 0.08 \\
\hline
\end{tabular}


2004). In a follow-up report, Raluy et al. (2005) has reported that, for a desalination plant using an energy source that is based on combustion of fossil fuel, carbon dioxide emissions of $1.78 \mathrm{~kg} / \mathrm{m}^{3}$ of desalted water and NOx emissions of $4.05 \mathrm{~g} / \mathrm{m}^{3}$ of desalted water were released. Together with the integration of the $\mathrm{RO}$ system with photovoltaic energy, $\mathrm{CO}_{2}$ emissions were reduced to between 0.6 and $0.9 \mathrm{~kg} / \mathrm{m}^{3}$ eq. and $\mathrm{NOx}$ emissions to between 1.8 and $2.1 \mathrm{~g} / \mathrm{m}^{3}$ (Raluy et al., 2005). A further decrease in environmental impact is achieved when wind energy is utilised in conjunction with the desalination plant with $\mathrm{CO}_{2}$ emissions of $0.1 \mathrm{~kg} / \mathrm{m}^{3}$ eq and NOx emissions of $0.4 \mathrm{~g} / \mathrm{m}^{3}$ (Raluy et al., 2005). Biwas (2009) reports for Western Australia a potential reduction of $\mathrm{CO}_{2}$ emissions from $3.80 \mathrm{~kg} / \mathrm{m}^{3}$ (electricity mix) to $0.32 \mathrm{~kg} / \mathrm{m}^{3}$ (100\% wind power) due to the replacement of conventional electricity by wind power. Stokes and Horvath (2009) show a similar trend for California where $\mathrm{CO}_{2}$ emissions were potentially reduced from $3.95 \mathrm{~kg} / \mathrm{m}^{3}$ to $0.72 \mathrm{~kg} / \mathrm{m}^{3}$ by replacing the US average electricity mix with $100 \%$ photovoltaic electricity. Thus, a substantial reduction in emission of GHG is theoretically possible by substituting fossil fuels with renewable energy sources. Another emerging renewable energy source not investigated in this research but appropriate for the desalination plant is the energy from ocean waves (Leijon and Boström, 2017).

Other available options to reduce the energy usage of a membrane-based water treatment plant include the implementation of a hybrid system which incorporates both brackish and seawater elements as well as a two-pass NF system (Veerapaneni et al., 2007 and Long, 2008). Investigation into innovative material based membranes that reduce fouling are also currently underway (Subramani et al., 2011). In addition, emerging technologies such as forward osmosis, ion concentration polarization and capacitive deionization technology are all advancements in the pipeline that could potentially have a positive impact on energy consumption (Elimelech and Phillip, 2011 and Subramani et al., 2011).

\section{Chemical requirements and the potential for improvement}

Chemical production and use also carries a significant burden for both case studies. In particular, the chemicals for posttreatment (lime and carbon dioxide) in the desalination process and for pre-treatment (ferric chloride as coagulant, secondary antiscalant and biocide) in the mine-water reclamation process appear in the modelling process as the chemicals with the highest impacts. This is in line with results reported by Vince et al. (2008). Large doses of chemicals are necessary in order to adjust the alkalinity of the demineralised water to potable water quality standards. For the selected desalination process, lime and $\mathrm{CO}_{2}$ release the highest amount of GHG emissions after electricity use. These results necessitate an investigation into alternate chemicals as well as permeate blending of the product water with other mineralised water sources in order to decrease chemical use.

Vince et al. (2008) carried out an analysis centred around various water treatment processes for particular local conditions. One of the conclusions that was reached pertains to the detrimental effect of coagulant production and use (Vince et al., 2008). As is evident from the treatment of minewater, the usage of coagulant depends on the concentration of organic and suspended matter in the source water. Vince et al. (2008) goes on to state that the production of a kilogram of ferric chloride has an impact on ozone depletion that is equal to the impact of $35 \mathrm{~kg}$ of aluminium sulphate. This brings to light the fact that the choice of similar chemicals may result in vastly different impacts. For the second case study, ferric chloride is responsible for $35 \%$ of the total potential for ozone depletion of the system. Thus, it is recommended that the production process of ferric chloride be investigated together with the consideration of other coagulants. In addition, it has been proven by Al-Mashharawi et al. (2012) that the use of low-pressure membranes in the pre-treatment phase has the capacity to reduce the use of coagulants. This should be also considered for the local desalination case study.

As far as the toxicity of discharged concentrate is concerned, Mezher et al. (2011) mentions that the overall temperature, density and total dissolved salts (TDS) of the discharge are of importance as they could potentially cause damage to the aquatic ecosystem. Increased temperature could have detrimental consequences while a rise in specific gravity would cause the contents of the reject stream to sink. The quantity of dissolved solids also increases with an increase in plant recovery. These factors need to be considered when debating the release of any concentrate into large bodies of water.

\section{CONCLUSIONS}

The results indicate that the operational phase is the predominant stage responsible for the majority of the environmental impacts attributed to both systems. Within this stage, the energy consumption is generally the greatest contributor, with chemical use representing the second-highest environmental burden. A detailed investigation of both water treatment processes reveals that the desalination process has a greater overall environmental impact than the mine-water reuse process, mainly due to the increased energy requirements. As the results indicate that plant impacts are highly dependent on the electricity supply source, further investigations of the substitution of fossil fuel-based energy with renewable energy were undertaken. It was calculated that the use of solar or wind energy could significantly reduce the climate change effect (i.e. reduce GHG emissions) of using seawater and mine-affected water to levels that are comparable to conventional water treatment processes currently employed in the eThekwini Municipality. Other technological developments should also be considered to reduce the energy and chemical usage of the system and can bring environmental improvments, in particular for the desalination plant as it is still in the planning process. In particular for this plant a pre-treatment stage and an overall optimization with regard to chemical usage should be investigated, as well as replacing chemicals with high environmental burdens. For long-term future developments of the RO processes for the production of potable water, the use of alternative sources of energy (solar and wind) should be promoted.

\section{ACKNOWLEDGEMENTS}

The authors would like to acknowledge the Water Research Commission for sponsorship of this study and Umgeni Water as well as Prentec for the provision of information.

\section{REFERENCES}

ABDELKREEM MA, ASSAD MEH, SAYED ET and SOUDAN B (2017) Recent progress in the use of renewable energy sources to power water desalination plants. Desalination 435 97-113. https:// doi.org/10.1016/j.desal.2017.11.018 
AL-MASHHARAWI S, GHAFFOUR N, AL-GHAMDI M and AMY G (2013) Evaluating the efficiency of different MF and UF membranes used as pretreatment for Red Seawater RO desalination. Desalin. Water Treat. 51 617-626. https://doi.org/10.1080/19443994.2012.6 99449

BARJOVEANU G, COMANDARU IM and TEODOSIU C (2010) Life cycle assessment of water and wastewater treatment systems: an overview. Bull. Polytech. Inst. Iasi 56 73-86.

BISWAS WK (2009) Life cycle assessment of sea water desalination in Western Australia. World Acad. Sci. Energ. Technol. 56 369-375.

BUCKLEY CA, FRIEDRICH E and VON BLOTTNITZ H (2011) Life cycle assessments (LCA) in the south african water sector: a review and future challenges. Water SA 37 (5) 718-726. https://doi. org/10.4314/wsa.v37i5.9

CHEW CM and NG KMD (2019) Feasibility of solar-powered ultrafiltration membrane water treatment systems for rural water supply in Malaysia. Water Supply 19 (6) 1758-1766. https://doi. org/10.2166/ws.2019.050

DOE (Department of Energy, South Africa) (2018) Integrated Resource Plan. URL: http://www.energy.gov.za/IRP/irp-update-draftreport2018/IRP-Update-2018-Draft-for-Comments.pdf (Accessed February 2019).

DWA (Department of Water Affairs, South Africa) (2013) National Water Resources Strategy. Department of Water Affairs, Pretoria, South Africa.

DOW FILMTEC (2015) Dow Filmtec Element. Dow Filmtec, United States of America.

ELIMELECH M and PHILLIP WA (2011) The future of seawater desalination: energy, technology, and the environment. Science 333 712-717. https://doi.org/10.1126/science.1200488

EUROPEAN COMMISSION (2010) International Reference Life Cycle Data System (ILCD) Handbook: General guide for Life Cycle Assessment - Detailed guidance. European Union, Ispra, Italy.

FRIEDRICH E (2002) Life-cycle assessment as an environmental management tool in the production of potable water. Water Sci. Technol. 46 (9) 29-36. https://doi.org/10.2166/wst.2002.0198

FRIEDRICH E, PILLAY S and BUCKLEY CA (2009) Environmental life cycle assessments for water treatment processes - A South African case study of an urban water cycle. Water SA 35 (1) 73-84. https://doi.org/10.4314/wsa.v35i1.76710

GOLDER ASSOCIATES AFRICA (2012) Environmental Impact Assessment (EIA) for the Proposed Water Reclamation Scheme - Draft Environmental Impact Assessment. Golder Associates Africa, Johannesburg.

HYDRANAUTICS (2016) Capillary Ultrafiltration Module. Lentech, Delft, The Netherlands.

LEIJON J and BOSTRÖM C (2017) Freshwater production from the motion of ocean waves. Desalination 435 161-171. https://doi. org/10.1016/j.desal.2017.10.049

ISO (2006) ISO 14040: Environmental Management - Life Cycle Assessment - Principles and Framework. International Organisation for Standardisation, Geneva.

ISO (2000) ISO 14042: Environmental Management - Life Cycle Assessment - Life Cycle Impact Assessment. International Organisation for Standardisation, Geneva.

KNÜPPE K (2011) The challenges facing sustainable and adaptive groundwater management in South Africa. Water SA 37 (1) 67-79. https://doi.org/10.4314/wsa.v37i1.64110

LONG B (2008) Optimisation of desalination for low energy. Singapore International Water Week, Singapore.

LOUBET P, ROUX P, LOISEAU E AND BELLON-MAUREL V (2014) Life cycle assessments of urban water systems: A comparative analysis of selected peer-reviewed literature. Water Res. 67 187-202. https://doi.org/10.1016/j.watres.2014.08.048

MEIER K (2012) Infrastructure Master Plan: Chapter 4.5 Wastewater reuse. Umgeni Water, Pietermaritzburg, South Africa.

MEIJERS K, VERBERNE AJP and KOREMAN EA (1998) Levenscyclusanalyse van membraanfiltraatie. $\mathrm{H}_{2} \mathrm{O} 21$ 33-36.

MEZHER T, FATH H, ABBAS Z and KHALED A (2011) Technoeconomic assessment and environmental impacts of desalination technologies. Desalination 266 (1) 263-273. https://doi. org/10.1016/j.desal.2010.08.035

PAUL SCHERRER INSTITUTE (2012) Electricity generation \& supply in ecoinvent v3. URL: https:/www.ecoinvent.org/ files/201206_bauer_electricity_in_ecoinvent_v3.pdf

(Accessed 1 June 2016).

PRENTEC (2013) Proposal for low waste mine water treatment plant. Prentec, Johannesburg, South Africa.

RALUY GR, SERRA L and UCHE J (2005) Life cycle assessment of water production technologies Part 1: Life cycle assessment of different commercial desalination technologies (MSF, MED, RO). The Int. J. Life Cycle Assess. 10 285-293. https://doi.org/10.1065/ lca2004.09.179.1

RALUY R, SERRA L, UCHE J and VALERO A (2004) Life-cycle assessment of desalination technologies integrated with energy production systems. Desalination 167 445-458. https://doi. org/10.1016/j.desal.2004.06.160

RAS C and VON BLOTTNITZ H (2012) A comparative life cycle assessment of process water treatment technologies at the Secunda Complex. Water SA 38 (4) 549-554. https://doi.org/10.4314/wsa. v38i4.10

SHAHABI MP, McHUGH A, ANDA M and HO G (2014) Environmental life cycle assessment of seawater reverse osmosis desalination plant powered by renewable energy. Renew. Energ. 67 53-58. https://doi.org/10.1016/j.renene.2013.11.050

STOKES JR and HORVATH A (2009) Energy and air emissions effects of water supply. Environ. Sci. Technol. 43 2680-2687. https://doi. org/10.1021/es801802h

SUBRAMANI A, BADRUZZAMAN M, OPPENHEIMER J and JACANGELO JG (2011) Energy minimization strategies and renewable energy utilization for desalination: A review. Water Res. 45 1907-1920. https://doi.org/10.1016/j.watres.2010.12.032

TURNER K, NAIDOO K, THERON J and BROODRUK J (2015) Investigation into the cost and operation of Southern African desalination and water reuse plants. WRC Report No. TT 636/15. Water Research Commission, Pretoria.

UMGENI WATER (2015a) KwaZulu-Natal East Coast Desalination Plants, Detailed Feasibility Study, Pipelines and Pump Stations Report. Umgeni Water, Pietermaritzburg, South Africa.

UMGENI WATER (2015b) KwaZulu-Natal East Coast Desalination Plants, Detailed Feasibility Study, Desalination Options and Feasibility Report. Umgeni Water, Pietermaritzburg, South Africa.

VEERAPANENI S, LONG B, FREEMAN S and BOND R (2007) Reducing energy consumption for desalination. J. Am. Water Works Assoc. 99 (6) 95-106. https://doi. org/10.1002/j.1551-8833.2007.tb07958.x

VINCE F, AOUSTIN E, BRÉANT P and MARECHAL F (2008) LCA tool for the environmental evaluation of potable water production. Desalination 220 (1-3) 37-56. https://doi.org/10.1016/j. desal.2007.01.021

ZHOU J, CHANG V W-C and FANE AG (2014) Life cycle assessment for desalination: A review on methodology feasibility and reliability. Water Res. 60 210-223. https://doi.org/10.1016/j. watres.2014.05.017 